Arq. Bras. Med. Vet. Zootec., v.68, n.3, p.553-561, 2016

\title{
Factors influencing colostrum yield by sows
}

[Fatores que influenciam a produção de colostro em porcas]

\author{
A.P. Machado ${ }^{I}$, M.A. Otto ${ }^{l}$, M.L. Bernardi ${ }^{2}$, I. Wentz $^{l}$, F.P. Bortolozzo ${ }^{1 *}$ \\ ${ }^{1}$ Faculdade de Medicina Veterinária - Universidade Federal do Rio Grande do Sul - Porto Alegre, RS \\ ${ }^{2}$ Faculdade de Agronomia - Universidade Federal do Rio Grande do Sul - Porto Alegre, RS
}

\begin{abstract}
An adequate colostrum intake, in order to ensure the survival and weight gain of piglets, depends on the sow's ability to produce enough colostrum for the whole litter. The aim of this study was to evaluate factors involved in colostrum yield (CY) variability related to the sow, the litter and the farrowing process. The experiment was conducted with 96 Camborough $25 \AA$ sows of parities one to seven, whose farrowing was spontaneous. Colostrum production of each sow was estimated by summing up the colostrum intake of each piglet in the litter, estimated by an equation that takes into account the birth weight and weight gain during the first $24 \mathrm{~h}$ of life. The multiple regression model explained $28 \%$ of variation in $\mathrm{CY}$, with $24 \%$ and $4 \%$ respectively of variation being explained by the litter birth weight and the width of the first mammary glands. Litter birth weight was positively correlated with the number of total born $(\mathrm{r}=0.73)$ and born alive piglets $(\mathrm{r}=0.83)$. When categorised into two groups of colostrum yield (LOWCY; $\leq 3.4 \mathrm{~kg}$; $\mathrm{n}=46$ vs HIGHCY; $>3.4 \mathrm{~kg}$; $\mathrm{n}=50$ ), LOWCY sows had fewer total born and born alive piglets and lighter litters $(\mathrm{P}<0.05)$. The logistic regression analysis showed that sows from parities 1 , 2 and $>3$ had greater odds $(\mathrm{P} \leq 0.05)$ of belonging to the LOWCY group than parity 3 sows. Sows with two or more obstetrical interventions had higher odds $(\mathrm{P}<0.05)$ of belonging to the LOWCY group than sows without interventions during farrowing. The higher colostrum yield observed in sows of parity 3 and sows with less than two obstetrical interventions during farrowing was associated with a greater number of nursed piglets. This study showed that total birth weight of born alive piglets is the most important factor involved in colostrum yield variability, indirectly representing the number of piglets nursed by the sow.
\end{abstract}

Keywords: litter weight, parity, obstetrical interventions

\section{RESUMO}

Um consumo adequado de colostro, para assegurar a sobrevivência e o ganho de peso, dos leitões, depende da capacidade da porca em produzir colostro suficiente para toda a leitegada. O objetivo deste estudo foi determinar fatores relacionados com a porca, com a leitegada ou com o parto que possam influenciar a produção de colostro (PC). O experimento foi conduzido com 96 porcas Camborough 25, de ordem de parto (OP) 1 a 7 , cujo parto foi espontâneo. A produção de colostro das porcas foi estimada pela soma do consumo individual de colostro pelos leitões, o qual foi estimado por equação que considera o peso ao nascimento e o ganho de peso nas primeiras $24 \mathrm{~h}$ de vida. Por meio de modelo de regressão múltipla, $28 \%$ da variação na PC foi explicada pelo peso da leitegada (24\%) e pela largura do primeiro par de glândulas mamárias (4\%). O peso da leitegada foi positivamente correlacionado com o número total de leitões nascidos $(r=0.73)$ e com o número de leitões nascidos vivos $(r=0.83)$. Quando separadas em dois grupos de PC (BAIXAPC; $\leq 3.4 \mathrm{~kg} ; n=46$ e ALTAPC; $>3.4 \mathrm{~kg} ; n=50)$, as porcas do grupo BAIXAPC tiveram menor número total de leitões nascidos, menor número de leitões nascidos vivos e leitegadas mais leves $(P<0.05)$. Por regressão logística, foi observado que porcas da OP 1,2 e $>3$ tiveram maior chance $(P \leq 0.05)$ de pertencer ao grupo BAIXAPC do que porcas de OP 3. Porcas com duas ou mais intervenções obstétricas tiveram maior chance $(P<0.05)$ de pertencer ao grupo BAIXAPC

Recebido em 30 de março de 2015

Aceito em 17 de novembro de 2015

* Autor para correspondência (corresponding author)

E-mail: fpbortol@ufrgs.br 
do que as porcas sem intervenção durante o parto. A maior PC observada nas porcas de OP 3 e nas porcas com menos intervenções obstétricas foi associada com um maior número de leitões amamentados. Foi mostrado, neste estudo, que o peso total da leitegada viva, o qual indiretamente representa o número de leitões amamentados pela porca, é o fator mais importante envolvido na produção de colostro.

Palavras-chave: peso da leitegada, ordem de parto, intervenção obstétrica

\section{INTRODUCTION}

In the last few decades, pig production has been marked by a higher pre-weaning mortality associated with the intensive selection of hyperprolific genetic lines. Most pre-weaning deaths occur within $72 \mathrm{~h}$ of birth and may be related to inadequate colostrum intake (Ferrari et al., 2014). Sufficient amounts of energy must be available or the piglet may die either because of hunger or crushed by the sow (reviewed by Theil et al., 2014). Colostrum provides newborn piglets with energy for thermoregulation and weight gain (Le Dividich et al., 2005), passive immunity for protection against pathogens during the first few weeks after birth (Rooke and Bland, 2002), and growth factors (Xu et al., 2000).

For an adequate colostrum intake, the piglet must be able to suckle colostrum from the teats and the sow must be capable of producing enough colostrum for the whole litter. Nevertheless, 35 to $55 \%$ of sows do not produce enough colostrum to fulfill the needs of their litter (Le Dividich et al., 2005; Quesnel et al., 2012; Decaluwé et al., 2014). Although colostrum yield can be affected by characteristics of the litter or of the environment, or a combination of both, the sow herself accounts for 65\% of variability in CY (Le Dividich et al., 2005). Therefore, the aim of this study was to evaluate factors involved in $\mathrm{CY}$ variability related to the sow, to the litter and to the farrowing process.

\section{MATERIAL AND METHODS}

The study included 96 sows from a breeding herd with 3900 sows in the Midwest of Santa Catarina State, Brazil, from February to April 2013, with the approval from the Institutional Animal Care and Use Committee (CEUA-UFRGS; experimental license number 24003). Sows of parity one to seven were from the same genetic line (Large White $x$ Duroc $x$ Landrace;

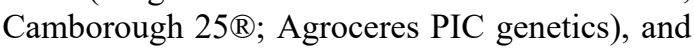
they were not induced to farrow.
The sows were observed from the transfer to farrowing rooms (110 days of gestation age) up to $24 \mathrm{~h}$ post partum. Each farrowing room had 66 farrowing crates where sows were kept until weaning day. Crates were equipped with nipples and automatic feeders and had a full plastic slatted floor. In front of each farrowing crate, there was a creep box containing a heated floor, heat lamp and an opening to permit free access to piglets. The room temperature was controlled by lateral curtain management. From 110 days of gestation until farrowing, sows were fed $2.0 \mathrm{~kg}$ of feed per day with a standard corn-soybean diet (18.5\% CP, $1.0 \%$ lysine and $3400 \mathrm{kcal} \mathrm{ME})$. The same diet was offered ad libitum after farrowing.

The interval from first insemination to farrowing date was considered as duration of gestation. All farrowing was supervised, and farrowing duration was considered the interval between the birth of the first and the last piglets. Sows' rectal temperature was measured immediately after the beginning of farrowing. The number of obstetrical interventions (i.e., oxytocin injection or manual intervention) and number of functional teats were also registered during the farrowing process.

One day after farrowing, all mammary measurements were performed using a measuring tape. The width of the first (WIDTH1) and fourth (WIDTH4) pairs of teats was measured by positioning the tape on the lateral insertion of the left gland and passing ventrally to the lateral insertion of the right gland from the corresponding pair. The length of the mammary complex, which was characterized as the mean value of the length of teats from both the right and left side, was obtained by positioning the measuring tape on the cranial insertion of the first gland and passing laterally until the caudal insertion of the last gland of each side.

Sows were weighed one day after farrowing with an electronic scale with $0.5 \mathrm{~kg}$ accuracy (EC 2000, Tru-test ${ }^{\circledR}$, Auckland, New Zeland). During 
the farrowing process, claw lesions were identified and rated based on severity (mild, moderate or severe), considering the following lesions: heel overgrowth and erosion (slight overgrowth and/or erosion in soft heel tissue; numerous cracks with obvious overgrowth and erosion; large amount of erosion and overgrowth with cracks throughout), separation at the heelsole juncture (slight; long; long and deep), separation along white line (shallow and/or short; long; long and deep), cracked wall horizontal (haemorrhage evident or short/shallow; long but shallow; multiple or deep), cracked wall vertical (short/shallow; long but shallow; multiple or deep).

Right after birth, piglets were dried with paper toweling, had their umbilical cords tied and were weighed with a digital scale with $1 \mathrm{~g}$ accuracy (UDC 6/1 POP, Urano ${ }^{\circledR}$, Canoas, Brazil). Thereafter, they were placed under a heating lamp next to the sow and had free access to the mammary complex, allowing them to express normal nursing behavior. Piglets were weighed again at $24 \mathrm{~h}$ after the onset of parturition. No creep feeding was offered to piglets, and no cross fostering was performed during this period. Weight data were used to estimate the individual colostrum intake, according to the equation proposed by Devillers et al. (2004), and considering the interval elapsed between birth and first suckling as 30 minutes. CY by sow was estimated by the sum of the individual colostrum intake of each piglet in the litter (Devillers et al., 2004).

All the statistical analyses were performed using the SAS software (SAS, 2005). Variables that had a normal distribution are presented as means \pm standard error of mean. The level of significance was $\mathrm{P}<0.05 ; \mathrm{P}$ values above 0.05 and below 0.10 were considered as tendency of significance.

Correlations were evaluated using the Pearson's coefficient (PROC CORR). A multiple regression model was run (PROC REG; stepwise selection) with 13 variables to explain variability of CY: sow's body weight, duration of gestation, duration of farrowing, sows' rectal temperature at farrowing, number of functional teats, length of mammary complex, WIDTH1, WIDTH4, number of total born piglets (TB), number of born alive piglets (BA), total weight of $\mathrm{BA}$ at birth (BWBA), mean birth weight of BA (MBWBA) and within-litter variation in birth weight of BA (CVBWBA). The variation inflation factor was used to measure the collinearity among independent variables and to remove those with redundant information in the other independent variables.

Five other variables that had a non-normal distribution were categorized into groups to investigate their effect on the risk of a low CY: parity $(1,2,3$ and $>3)$, number of obstetrical interventions $(0,1$ and $>1)$, number of stillborn piglets $(0,1$ and $>1)$, number of mummified piglets $(0,1$ and $>1)$, type of claw lesion (1 severe lesions only, or severe lesions associated with moderate and/or mild lesions; 2 - moderate lesions only, or moderate lesions associated with mild lesions; 3 - mild lesions only, or no lesions). Univariate models of logistic regression (PROC GLIMMIX) were used, considering the occurrence of low CY as the dependent variable. For these analyses, sows were categorized into two groups based on the CY median: LOWCY colostrum yield $\leq 3.4 \mathrm{~kg}(\mathrm{n}=46)$ and HIGHCY colostrum yield $>3.4 \mathrm{~kg}(\mathrm{n}=50)$.

Analyses of variance (PROC MIXED) were used to compare litter and sow characteristics between LOWCY and HIGHCY groups. The percentages of stillborn piglets and mummified fetuses were submitted to a nonparametric analysis (PROC NPAR1WAY), and the Wilcoxon test was used to compare the two CY groups. In another approach, analysis of variance (PROC MIXED) was also used to explore the relationships between significant variables derived from multiple regression model and logistic regression models.

\section{RESULTS}

Overall, the sows had $3.0 \pm 0.18$ parities, $14.2 \pm$ 0.12 functional teats, $13.2 \pm 0.32 \mathrm{~TB}, 12.1 \pm 0.31$ $\mathrm{BA}, 16.1 \pm 0.37 \mathrm{~kg}$ BWBA, and $19.1 \% \pm 0.65$ within-litter CVBWBA.

The estimated colostrum yield in $24 \mathrm{~h}$ varied from 0.9 to $5.9 \mathrm{~kg}$ and averaged $3.4 \mathrm{~kg} \pm 0.10 \mathrm{~kg}$. Colostrum yield was positively correlated $(\mathrm{P} \leq 0.05)$ with TB, BA, BWBA, WIDTH1 and WIDTH4 (Table 1). Stepwise multiple regression analysis showed that $28 \%$ of variation in $\mathrm{CY}$ was explained by two variables (Figure $1 ; \mathrm{P}<0.05$ ) BWBA and WIDTH1 $(\mathrm{CY}=0.31+0.13 \mathrm{BWBA}$ 
+0.04 WIDTH1). The other 11 continuous variables did not remain in the model, either because they were not significant or because of multicollinearity. There were positive correlations $(\mathrm{P}<0.05)$ between the two variables significant in regression analysis and the other tested variables: BWBA was correlated with TB $(\mathrm{r}=0.73)$ and BA $(\mathrm{r}=0.83)$, whereas WIDTH1 was correlated with WIDTH4 $(\mathrm{r}=0.90)$.

Table 1. Correlation of colostrum yield with sow and litter characteristics

\begin{tabular}{lcc}
\hline & & \\
Variables & Correlation coefficient & P-Value \\
\hline Duration of gestation, days & 0.034 & 0.7454 \\
Sow body weight at farrowing, kg & 0.007 & 0.9444 \\
Sow temperature at farrowing, ${ }^{\circ} \mathrm{C}$ & -0.135 & 0.1884 \\
Duration of farrowing, h & 0.075 & 0.4679 \\
Number of functional teats & 0.055 & 0.5930 \\
Length of mammary complex, cm & -0.080 & 0.4353 \\
Width of first (WIDTH1) pair of teats & 0.254 & 0.0124 \\
Width of fourth (WIDTH4) pair of teats & 0.199 & 0.0514 \\
Total born piglets - TB & 0.356 & 0.0004 \\
Born alive piglets - BA & 0.394 & $<0.0001$ \\
Total weight at birth of BA - BWBA & 0.495 & $<0.0001$ \\
Mean birth weight of BA (MBWBA) & 0.008 & 0.9364 \\
Within-litter birth weight variation -CVBWBA & -0.030 & 0.7723 \\
\hline
\end{tabular}

The LOWCY sows had lower TB, BA and BWBA, and their piglets suckled less colostrum than piglets born from HIGHCY sows $(\mathrm{P}<0.05$; Table 2). Sows of parities 1, 2 and 4-7 had higher odds ratios $(\mathrm{P} \leq 0.05)$ of belonging to the LOWCY group than parity 3 sows (Table 3 ). Sows that received two or more obstetrical interventions during the farrowing process had higher odds ratios $(\mathrm{P}<0.05)$ of belonging to the LOWCY group than sows with no obstetrical interventions. The number of stillborn piglets, mummified fetuses and types of claw lesion were not risk factors for a low CY $(\mathrm{P}>0.05)$.

Sows belonging to parities 1,2 and 4-7 had litters with lower $(\mathrm{P}<0.05)$ BWBA than parity 3 sows (Table 4). Lighter litters were also observed in sows that received two or more obstetrical interventions when compared to sows with no obstetrical interventions. The WIDTH1 was similar among classes of parity order and obstetrical interventions $(\mathrm{P}>0.05)$.

\section{DISCUSSION}

Taking into account a colostrum intake of $250 \mathrm{~g}$, recommended to achieve good health and preand post-weaning growth (Quesnel et al., 2012), $35.4 \%, \quad 37.6 \%$ and $53.1 \%$ respectively of sows in the present study did not produce enough colostrum to nurse 12,13 and 14 born alive piglets, respectively. These numbers are in agreement with previous studies that demonstrated an insufficient colostrum yield by 35 to $55 \%$ of sows to fulfill the requirements of the entire litter (Le Dividich et al., 2005; Quesnel et al., 2012; Decaluwé et al., 2014).

The most important factor involved in $\mathrm{CY}$ variability was the total birth weight of born alive piglets, reinforcing the tendency of a positive correlation between litter weight and CY, as reported by Devillers et al. (2007). The positive correlation between weight and the number of born alive piglets indicates indirectly that litter size affects CY. This assumption was also strengthened by the larger litter size observed in HIGHCY sows. In the first hours after farrowing, colostrum is ad libitum available, and nursing is asynchronous and continuous (Levis and Hurnik, 1985); this makes colostrum withdrawal easy, because it is less dependent on colostrum ejection episodes (Fraser and Rushen, 1992). Larger and heavier litters may take advantage of this phenomenon and be able to obtain a greater colostrum extraction from the mammary glands. Later, a mechanism similar to that observed for milk production can be established where there is a positive association between the number of suckling piglets and the amount of milk produced (Audist et al., 1998). 

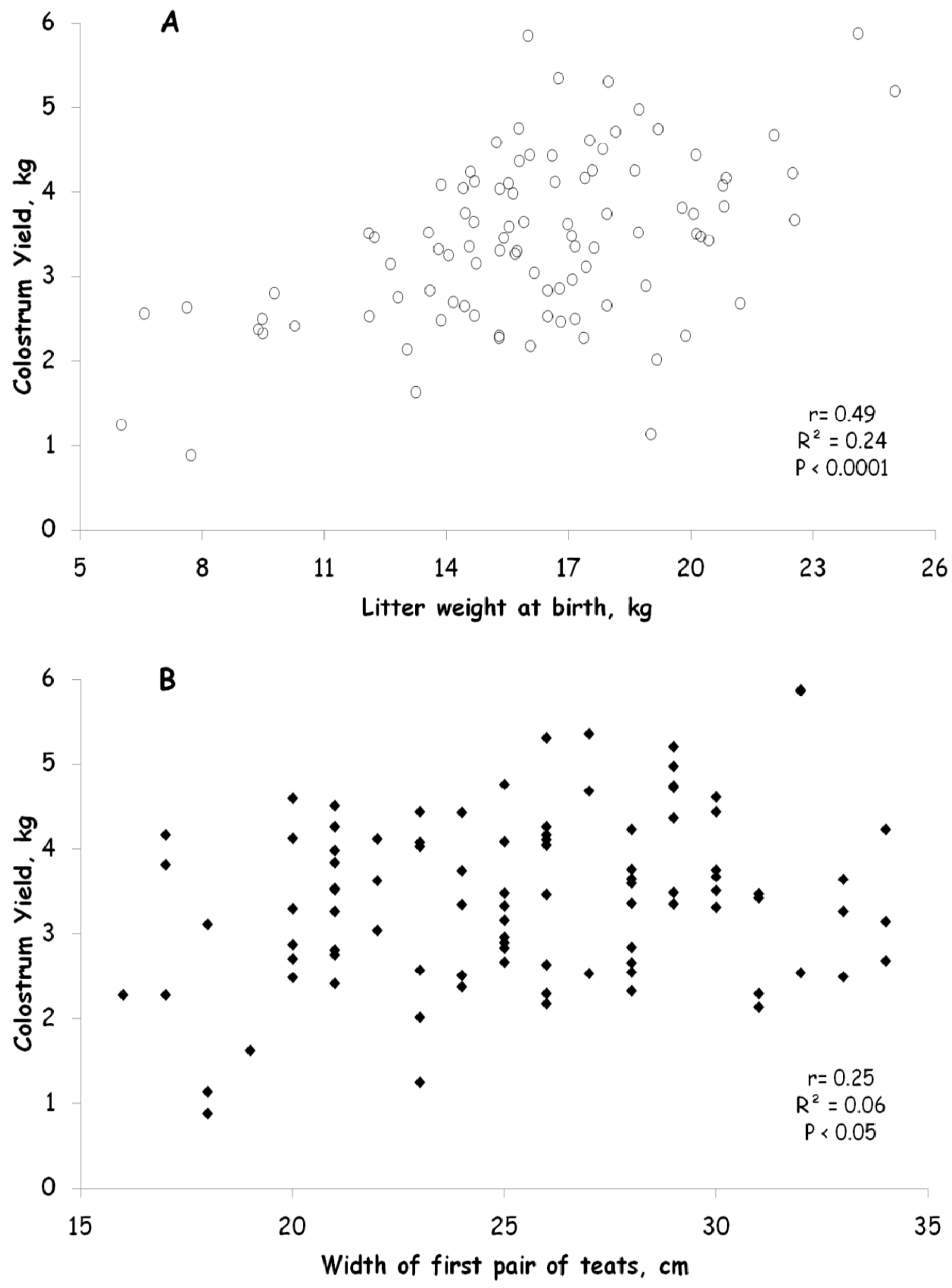

Figure 1. Correlation between colostrum yield and total litter weight at birth (A), and between colostrum yield and width of first pair of teats (B). 
Table 2. Characterisation of sows and their litters according to groups of colostrum yield

\begin{tabular}{|c|c|c|c|c|}
\hline Variables & $\begin{array}{c}\text { LOW } \\
\leq 3.4 \mathrm{~kg} \\
(\mathrm{n}=46)\end{array}$ & $\begin{array}{c}\text { HIGH } \\
>3.4 \mathrm{~kg} \\
(\mathrm{n}=50)\end{array}$ & $\begin{array}{c}\text { Pooled } \\
\text { standard } \\
\text { error }\end{array}$ & P-value \\
\hline Colostrum yield, kg & 2.6 & 4.2 & 0.12 & $<0.0001$ \\
\hline Mean colostrum intake, g/piglet & 269.1 & 339.6 & 18.30 & 0.0002 \\
\hline Parity order & 3.2 & 2.9 & 0.36 & 0.448 \\
\hline Sow's body weight at farrowing, $\mathrm{kg}$ & 229.3 & 227.7 & 6.90 & 0.820 \\
\hline Duration of gestation, days & 114.5 & 114.6 & 0.20 & 0.696 \\
\hline Duration of farrowing, minutes & 189.4 & 193.3 & 19.5 & 0.842 \\
\hline Temperature at farrowing, ${ }^{\circ} \mathrm{C}$ & 38.6 & 38.5 & 0.11 & 0.655 \\
\hline Functional teats, $\mathrm{n}^{\circ}$ & 14.2 & 14.2 & 0.24 & 0.943 \\
\hline Length of mammary complex, $\mathrm{cm}$ & 75.3 & 74.2 & 1.34 & 0.414 \\
\hline Width of first pair of teats, $\mathrm{cm}$ & 24.8 & 25.9 & 0.91 & 0.208 \\
\hline Width of fourth pair of teats, $\mathrm{cm}$ & 32.9 & 33.8 & 1.23 & 0.460 \\
\hline Total born piglets (TB), $\mathrm{n}$ & 12.3 & 14.0 & 0.63 & 0.007 \\
\hline Born alive piglets (BA), $n$ & 11.0 & 13.1 & 0.58 & 0.0005 \\
\hline Total birth weight of BA, $\mathrm{kg}$ & 14.4 & 17.6 & 0.67 & $<0.0001$ \\
\hline Mean birth weight of BA, kg & 1.4 & 1.4 & 0.04 & 0.993 \\
\hline Within-litter CV birth weight of BA, \% & 19.6 & 18.5 & 1.31 & 0.424 \\
\hline Stillborn piglets $1, \%$ & $5.4(0-31.2)$ & $3.3(0-23.1)$ & 1.39 & 0.288 \\
\hline Mummified piglets $1, \%$ & $5.1(0-38.5)$ & $3.2(0-16.7)$ & 1.36 & 0.563 \\
\hline \multicolumn{5}{|l|}{ Sows with claw lesion $2, \%$} \\
\hline Type $1, \%$ & 15.2 & 12.0 & - & 0.645 \\
\hline Type $2, \%$ & 60.9 & 72.0 & - & 0.248 \\
\hline Type $3, \%$ & 23.9 & 16.0 & - & 0.331 \\
\hline
\end{tabular}

${ }^{1}$ Data shown as mean (median-maximum).

${ }^{2}$ Type of claw lesions: 1 - severe lesions only, or severe lesions associated with moderate and/or mild lesions; 2 moderate lesions only, or moderate lesions associated with mild lesions; 3 - mild lesions only, or no lesions.

Table 3. Results of logistic regression analysis used to investigate the effect of categorical variables on the risk of low colostrum yield (CY) in sows

\begin{tabular}{|c|c|c|c|}
\hline Groups & $\begin{array}{c}\mathrm{CY} \leq 3.4 \mathrm{~kg} \\
\%(\mathrm{n} / \mathrm{n})\end{array}$ & $\begin{array}{l}\text { Odds Ratio } \\
\text { (CI 95\%) }\end{array}$ & P-value \\
\hline \multicolumn{4}{|l|}{ Parity } \\
\hline 1 & $57.1(12 / 21)$ & $5.7(1.4-23.2)$ & 0.0164 \\
\hline 2 & $47.8(11 / 23)$ & $3.9(1.0-15.5)$ & 0.0534 \\
\hline 3 & $19.0(4 / 21)$ & 1 & - \\
\hline$>3$ & $61.3(19 / 31)$ & $6.7(1.8-25.3)$ & 0.0053 \\
\hline \multicolumn{4}{|c|}{ Obstetrical interventions } \\
\hline 0 & $41.4(29 / 70)$ & 1 & - \\
\hline 1 & $41.7(5 / 12)$ & $1.0(0.3-3.5)$ & 0.9877 \\
\hline$>1$ & $85.7(12 / 14)$ & $8.5(1.7-41.6)$ & 0.0090 \\
\hline \multicolumn{4}{|c|}{ Stillborn piglets } \\
\hline 0 & $45.9(28 / 61)$ & 1 & - \\
\hline 1 & $40.0(8 / 20)$ & $0.8(0.3-2.2)$ & 0.6463 \\
\hline$>1$ & $66.7(10 / 15)$ & $2.4(0.7-7.8)$ & 0.1597 \\
\hline \multicolumn{4}{|c|}{ Mummified foetuses } \\
\hline 0 & $47.5(28 / 59)$ & 1 & - \\
\hline 1 & $46.1(12 / 26)$ & $0.9(0.4-2.4)$ & 0.9119 \\
\hline$>1$ & $54.5(6 / 11)$ & $1.3(0.4-4.9)$ & 0.6675 \\
\hline \multicolumn{4}{|c|}{ Claw lesions1 } \\
\hline 1 & $53.8(7 / 13)$ & $0.8(0.2-3.6)$ & 0.8212 \\
\hline 2 & $43.7(28 / 64)$ & $0.6(0.2-1.6)$ & 0.2839 \\
\hline 3 & $57.9(11 / 19)$ & 1 & - \\
\hline
\end{tabular}

$\mathrm{CI}=$ confidence interval.

${ }^{1}$ Type of claw lesions: 1 - severe lesions only, or severe lesions associated with moderate and/or mild lesions; 2 moderate lesions only, or moderate lesions associated with mild lesions; 3 - mild lesions only, or no lesions. 
Table 4. Total birth weight of born alive piglets (BWBA) and width of first (WIDTH1) pair of teats according to groups of parity or obstetrical interventions in sows

\begin{tabular}{|c|c|c|}
\hline Groups & $\begin{array}{l}\text { BWBA, } \\
\text { kg }\end{array}$ & WIDTH1, cm \\
\hline \multicolumn{3}{|l|}{ Parity } \\
\hline 1 & $16.2 \mathrm{abC}$ & 24.3 \\
\hline 2 & $15.9 b$ & 25.4 \\
\hline 3 & $18.2 \mathrm{aD}$ & 26.3 \\
\hline$>3$ & $14.7 \mathrm{~b}$ & 25.3 \\
\hline $\begin{array}{l}\text { Pooled standard } \\
\text { error } \\
\text { Obstetrical interv }\end{array}$ & $\begin{array}{l}1.43 \\
\text { tions }\end{array}$ & 1.87 \\
\hline 0 & $16.9 \mathrm{a}$ & 25.8 \\
\hline 1 & $16.0 \mathrm{a}$ & 24.3 \\
\hline$>1$ & $12.2 \mathrm{~b}$ & 24.2 \\
\hline $\begin{array}{c}\text { Pooled } \\
\text { standard error }\end{array}$ & 1.34 & 1.84 \\
\hline \multicolumn{3}{|c|}{$\begin{array}{l}\text { Values with different superscripts in the column differ } \\
\text { significantly }(\mathrm{P}<0.05) \text { among parities or obstetrical } \\
\text { interventions groups. } \\
C, D \text { Indicates tendency of difference among parity } \\
\text { order groups }(\mathrm{P}=0.06) \text {. }\end{array}$} \\
\hline
\end{tabular}

Heavier piglets are expected to be more able to reach teats and suckle colostrum, probably due to their higher vigor and lower sensitivity to cold temperatures (Herpin et al., 2002). However, in contrast to Devillers et al. (2007), it was observed that mean piglet birth weight and litter weight variation at birth were not related to colostrum yield. In fact, these variables did not differ between piglets born from HIGHCY and LOWCY sows. These results are in accordance with the observed for milk yield, which can be enhanced by increasing demand due to more frequent suction (Auldist et al., 2000), larger litters (Auldist et al., 1998) and heavier litters (King et al., 1997).

A greater number of teats being stimulated could lead to a greater amount of colostrum released, in the same manner by which milk yield is enhanced (Auldist et al., 1998 and 2000; Marshal et al., 2006). This fact was observed in this study because HIGHCY sows had approximately two more piglets born alive than LOWCY sows. Although less colostrum is usually available for individual intake in larger litters (Le Dividich et al., 2004), HIGHCY sows were more competent, regardless of their larger litters, in fulfilling the requirements of their litters, since their piglets consumed $70 \mathrm{~g}$ of colostrum more than LOWCY piglets.

Considering that milk production is associated with the number of cells in the mammary parenchyma and that average daily gain of the piglets has been positively correlated to the amount of mammary tissue (Nielsen et al., 2001), another factor that could influence CY is the development of the mammary complex. Many techniques have been used to estimate the development and production of the mammary complex, for example, cross-sectional area (Kim et al., 1999), individual and collective weight of mammary glands (Ji et al., 2005), and amount of parenchymal DNA and RNA (Farmer et al., 2012). However, to use any one of these techniques, it is necessary to slaughter the sow and dissect the mammary tissue. Seeking the welfare and permanence of sows in the herd, this study proposed to use measures of mammary complex to estimate the development and production of mammary glands and, consequently, the CY. The WIDTH1 was revealed as an explaining factor for $\mathrm{CY}$, but its individual contribution was low.

The effect of parity on CY remains inconsistent, because Quesnel (2011) did not observe any effect of parity on CY, whereas Devillers et al. (2007) found a tendency of lower CY in primiparous and older sows (parity $>3$ ) compared to sows of parity 2 and 3 . Although parity and sow body weight were correlated $(r=0.66$; $\mathrm{P}<0.0001$ ), body weight alone did not explain CY, as already shown by Devillers et al., 2007). This aspect was also reinforced by similar body weight between LOWCY and HIGHCY sows. Recently, the lower production of older sows (parity $\geq 4$ ) was explained partially by greater backfat thickness loss in late gestation and by shorter gestation length (Decaluwé et al., 2013). Ferrari et al. (2014) observed a higher CY in parity 4 and 5 sows compared with primiparous sows, in spite of their similar litter sizes and mean birth weight of born alive piglets. Taken together, these observations show that there are some underlying factors that may explain the effect of parity on CY. In the present study, the higher $\mathrm{CY}$ of parity 3 sows may be explained, at least partially, by the larger number of suckling 
piglets and heavier litters, compared with younger and older sows.

Obstetrical interventions during farrowing are recommended mainly to reduce stillbirth occurrence. It is well known that larger litters are associated with longer farrowings (Van Dijk et al., 2005) and with greater risk of stillbirth (Holyoake et al., 1995). A possible explanation for low CY in sows that experienced two or more obstetrical interventions could be the greater number of stillborn piglets, since a negative association between stillbirth and $\mathrm{CY}$ has been described previously (Quesnel, 2011). However, in our study, this hypothesis was ruled out because sows with more obstetrical interventions did not have more stillborn piglets (data not shown). On the other hand, it has been demonstrated that obstetrical interventions are sometimes used to check for more piglets in the reproductive tract, not necessarily representing a dystocic delivery (Borges et al., 2005). This probably occurred in the present study, since sows with more obstetrical interventions, contrary to expectations, had smaller litters. Thus, the low CY of these sows was due to a low number of nursed piglets rather than to the number of obstetrical interventions itself.

Locomotory disorders could cause disturbances of animal welfare and financial losses (Anil et al., 2005). Although the presence of inflammatory process in the claw (lameness) is associated with reduced milk production in cows (Warnick et al., 2001), no information is available concerning lameness and milk or colostrum production in sows. Productive performance of sows can be compromised by deep claw lesions that hurt the chorionic tissue, resulting in inflammatory response, pain and claudication (Wilson et al., 2012). The absence of claw lesion effects on $\mathrm{CY}$ in this study is probably due to a low severity of the observed lesions. Even sows considered to have severe types of claw lesions did not show pyrexia, anorexia or symptoms of locomotory disorders (data not shown).

\section{CONCLUSIONS}

Colostrum yield is positively associated with total birth weight of born alive piglets, and with width of first pair of teats. A higher colostrum yield, observed in sows of parity 3 and sows with less than two obstetrical interventions during farrowing, is associated with a greater number of nursed piglets.

\section{ACKNOWLEDGEMENTS}

The authors are grateful to Master Genética Animal for providing the facilities to perform this study, and to Agroceres PIC for financial support for this project.

\section{REFERENCES}

ANIL, S.S.; ANIL, L.; DEEN, J. Evaluation of patterns of removal and associations among culling because of lameness and sow productivity traits in swine breeding herds. $J$. Am. Vet. Med. Assoc., v.226, p.956-961, 2005.

AULDIST, D.E.; MORRISH, L.; EASON, P.; KING, R.H. The influence of litter size on milk production of sows. Anim. Sci., v.67, p.333-337, 1998.

AULDIST, D.E.; CARLSON, D.; MORRISH, L.; WAKEFORD, C.M. et al. The influence of suckling interval on milk production of sows. $J$. Anim. Sci., v.78, p.2026-2031, 2000.

BORGES, V.F.; BERNARDI, M.L.; BORTOLOZZO, F.P.; WENTZ, I. Risk factors for stillbirth and foetal mummification in four Brazilian swine herds. Prev. Vet. Med., v.70, p.165-176, 2005.

DECALUWÉ, R.; MAES, D.; DECLERCK, I.; COOLS, A. et al. Changes in back fat thickness during late gestation predict colostrum yield in sows. Animal, v.7, p.1999-2007, 2013.

DECALUWÉ, R.; MAES, D.; WUYTS, B.; COOLS, A. et al. Piglets' colostrum intake associates with daily weight gain and survival until weaning. Livest. Sci., v.162, p.185-192, 2014.

DEVILLERS, N.; VAN MILGEN, J.; PRUNIER, A.; LE DIVIDICH, J. Estimation of colostrum intake in the neonatal pig. Anim. Sci., v.78, p.305-313, 2004.

DEVILLERS, N.; FARMER, C.; LE DIVIDICH, J.; PRUNIER, A. Variability of colostrum yield and colostrum intake in swine. Animal, v.1, p.1033-1041, 2007. 
FARMER, C.; PALIN, M.F.; THEIL, P.K.; SORENSEN, M.T. et al. Milk production in sows from a teat in second parity is influenced by whether it was suckled in first parity. J. Anim. Sci., v.90, p.3743-3751, 2012.

FERRARI, C.V.; SBARDELLA, P.E.; BERNARDI, M.L.; COUTINHO, M.L. et al. Effect of birth weight and colostrum intake on mortality and performance of piglets after crossfostering in sows of different parities. Prev. Vet. Med., v.114, p.259-266, 2014.

FRASER, D.; RUSHEN, J. Colostrum intake by newborn piglets. Can. J. Anim. Sci., v.72, p.1-13, 1992.

HERPIN, P.; DAMON, M.; LE DIVIDICH, J. Development of thermoregulation and neonatal survival in pigs. Livest. Prod. Sci., v.78, p.25-45, 2002.

HOLYOAKE, P.K.; DIAL，G.D.; TRIGG, T.; KING, V.L. Reducing pig mortality through supervision during the perinatal period. J. Anim. Sci., v.73, p.3543-3551, 1995.

JI, F.; WU, G.; BLANTON, J.R.; KIM, S.W. Changes in weight and composition in various tissues of pregnant gilts and their nutritional implications. J. Anim. Sci., v.83, p.366-375, 2005.

KIM, S.W.; HURLEY, W.L.; HAN, I.K.; EASTER, R.A. Changes in tissue composition associated with mammary gland growth during lactation in sows. J. Anim. Sci., v.77, p.25102516, 1999.

KING, R.H.; MULLAN, B.P.; DUNSHEA, F.R.; DOVE, $H$. The influence of piglet body weight on milk production of sows. Livest. Prod. Sci., v.47, p.169-174, 1997.

LE DIVIDICH, J.; MARTINEAU, G.P.; THOMAS, F.; DEMAY, H. et al. Acquisition de l'immunité passive chez les porcelets et production de colostrum chez la truie. J. Rech. Porc., v.36, p.451-456, 2004.

LE DIVIDICH, J.; ROOKE, J.A.; HERPIN, P. Review: nutritional and immunological importance of colostrum for the newborn pig. $J$. Agric. Sci., v.143, p.469-485, 2005.

LEWIS, N.J.; HURNIK, J.F. The development of nursing behaviour in swine. Appl. Anim. Behav. Sci., v.14, p.225-232, 1985.
MARSHAL, K.M.; HURLEY, W.L.; SHANKS, R.D.; WHEELER, M.B. Effects of suckling intensity on milk yield and piglet growth from lactation-enhanced gilts. J. Anim. Sci., v.84, p.2346-2351, 2006.

NIELSEN, O.L.; PEDERSON, A.R.; SORENSEN, M.T. Relationships between piglet growth rate and mammary gland size of the sow. Livest. Prod. Sci., v.67, p.273-279, 2001.

QUESNEL, H. Colostrum production by sows: variability of colostrum yield and immunoglobulin G concentrations. Animal, v.5, p.1546-1553, 2011.

QUESNEL, H.; FARMER, C.; DEVILLERS, $\mathrm{N}$. Colostrum intake: influence on piglet performance and factors of variation. Livest. Sci., v.146, p.105-114, 2012.

ROOKE, J.A.; BLAND, I.M. The acquisition of passive immunity in the newborn piglet. Livest. Prod. Sci., v.78, p.13-23, 2002.

SAS/STAT software. Version 9.1.3, Cary, NC: SAS Institute Inc., 2005.

THEIL, P.K.; LAURIDSEN, C.; QUESNEL, H. Neonatal piglet survival: impact of sow nutrition around parturition on fetal glycogen deposition and production and composition of colostrum and transient milk. Animal, v.8, p.1021-1030, 2014.

VAN DIJK, A.J.; VAN RENS, B.T.T.M.; VAN DER LENDE, T.; TAVERNE, M.A.M. Factors affecting duration of the expulsive stage of parturition and piglet birth intervals in sows with uncomplicated, spontaneous farrowings. Theriogenology, v.64, p.1573-1590, 2005.

WARNICK, L.D.; JANSSEN, D.; GUARD, C.L.; GROHN, Y.T. The effects of lameness on milk production in dairy cows. J. Dairy Sci., v.84, p.1988-1997, 2001.

WILSON, M.E.; TORRISON, J.L.; FIREMAN, A.K. A claudicação impacta a longevidade e o potencial reprodutivo da porca. In: FÓRUM INTERNACIONAL DE SUINOCULTURA, 6., 2012, Curitiba, PR Anais... Concórdia: Embrapa Suínos e Aves; Curitiba: AnimalWord, 2012. p.167-175.

XU, R.J., WANG, F., ZHANG, S.H. Postnatal adaptation of the gastrointestinal tract in neonatal pigs: a possible role of milk-borne growth factors. Livest. Prod. Sci., v.66, p.95-107, 2000. 